REVIEW

\title{
Probiotics and prebiotics in the elderly
}

\section{J M T Hamilton-Miller}

Postgrad Med J 2004;80:447-451. doi: 10.1136/pgmj.2003.015339

Probiotics (usually lactobacilli and bifidobacteria) and prebiotics (non-digestible oligosaccharides) have been shown to be useful in preventing certain disease conditions as well as possibly promoting specific aspects of health. In the present review, the evidence from clinical trials for benefits from probiotics and prebiotics to elderly populations is presented and discussed, specifically in respect of three common conditions found in the elderly. Both probiotics and prebiotics may be helpful in malnutrition, particularly in lactose intolerance and calcium absorption, and in constipation. Probiotics have been shown clearly to boost immunity in the elderly, but the clinical significance of this remains to be clarified. These results are encouraging, and further large scale studies seem justified to establish the place of probiotic and prebiotic supplements in elderly subjects.

Correspondence to: Professor J M T HamiltonMiller, Department of Medical Microbiology, Royal Free and University College Medical School, Rowland Hill St, London NW3 2PF, UK; j.hamilton-miller@ rfc.ucl.ac.uk

Submitted

26 September 2003

Accepted 20 January 2004
$\mathrm{P}$ robiotics-a word derived from Latin and Greek meaning literally "for life" — has been defined in many ways since it was first coined 50 years ago. ${ }^{1}$ The most recent consensus is "defined, live micro-organisms administered in adequate amounts which confer a beneficial physiological effect on the host". ${ }^{\prime 2}$ While the concept that consuming large numbers of live bacteria can promote health and prevent and cure disease may at first seem strange, the usefulness of probiotics is rapidly becoming apparent.

Probiotics are usually bacterial components of the normal human intestinal flora, for example lactobacilli and bifidobacteria, that produce as end products of metabolism lactate and short chain fatty acids such as acetate and butyrate. Certain specific probiotic strains (for example, Lactobacillus rhamnosus GG, L plantarum 299v, $L$ casei Shirota and $L$ johnsonii Lal) have well defined and proven clinical effects for the treatment and/or prevention of diseases of intestinal and extraintestinal origin. These effects have been extensively reviewed recently. ${ }^{3}$

Lactic acid producing bacteria (LAB) have been used, unwittingly, for centuries to preserve food (for example, sauerkraut), and most countries developed their own characteristic type of fermented milk. ${ }^{5}$ The first deliberate use of LAB for health reasons was by Metchnikoff early in the 20th century as a possible antidote to the aging process, proposed by him to be at least partly due to toxins produced by putrefactive intestinal bacteria (that is, not LAB). After some initial enthusiasm, interest waned, ${ }^{6}$ and probiotics did not become popular until the public embraced the idea of functional foods ("foods that provide physiological benefits or reduce the risk of chronic diseases, over and above their basic nutritional value") during the last decade of the 20th century. Metchnikoff's theory that gut flora contribute in some way to aging was supported in the 1950s, by the finding that germ-free animals live longer than their conventional counterparts. ${ }^{7}$

Today, probiotics are familiar to the public as the components of bioyoghurts and dietary supplements, are widely available, and extensively purchased. In 1997, Europeans spent the equivalent of almost $\$ 900$ million on probiotic yoghurts and milks, and this market is growing rapidly. ${ }^{8}$

Prebiotics are a more recent concept, first defined less than 10 years ago. ${ }^{9}$ They are chemical substances, usually oligosaccharides, that act as substrates specifically for the host's intrinsic probiotic bacteria, and thus encourage their growth. Prebiotics are selected as being non-digestible by the host and not metabolised by non-probiotic gut flora such as Bacteroides spp and Escherichia coli. Prebiotics are available naturally in breast milk and in certain vegetables (for example, Jerusalem artichokes and onions), and as synthetic oligosaccharides based on fructose or galactose, known as FOS and GOS respectively. ${ }^{10}$ The latter can be added to foods, or combined with a probiotic to make a synbiotic.

It is the purpose of this review to describe ways in which use of probiotics, and possibly prebiotics, might benefit elderly subjects in respect of three commonly occurring conditionsnamely, constipation, undernutrition, and diminishing efficiency of the immune system.

\section{AVAILABILITY OF PROBIOTICS AND PREBIOTICS}

\section{Probiotics}

Products containing probiotic bacteria are readily available to the public, the most common being yoghurt. The standard type of yoghurt consists of milk (usually from the cow, but milk from the goat or sheep may also be used) fermented by bacteria that convert lactose into lactic acid (see table 1).

Lactic acid gives the yoghurt its characteristic sharp taste (usually modulated with sweeteners and flavouring) and also denatures and precipitates casein, resulting in a semisolid consistency. So-called "bioyoghurts" are produced in a

Abbreviations: FOS, synthetic oligosaccharide based on fructose; GOS, synthetic oligosaccharide based on glucose; LAB, lactic acid producing bacteria; NK, natural killer (cells) 
Table 1 Examples of availability of probiotics in various forms

\begin{tabular}{|c|c|c|c|}
\hline Type of probiotic & Example & Biological effects & Comments \\
\hline \multicolumn{4}{|l|}{ Yoghurt } \\
\hline Classical type & $\begin{array}{l}\text { Lactobacillus delbrueckii } \\
\text { var bulgaricus; } \\
\text { Streptococcus salivarius } \\
\text { var thermophilus }\end{array}$ & $\begin{array}{l}\text { Biological effects shown } \\
\text { (but limited); very palatable }\end{array}$ & $\begin{array}{l}\text { Products often pasteurised; } \\
\text { component bacteria cannot } \\
\text { colonise gut; short shelf life; } \\
\text { bacterial numbers not stated }\end{array}$ \\
\hline "Bio" type & $\begin{array}{l}\text { Lactobacillus acidophilus; } \\
\text { bifidobacteria may also } \\
\text { be present }\end{array}$ & $\begin{array}{l}\text { Wide range of biological } \\
\text { effects; component bacteria } \\
\text { colonise gut; very palatable }\end{array}$ & $\begin{array}{l}\text { Short shelf life; bacterial numbers } \\
\text { not stated; component bacteria } \\
\text { often not adequately identified }\end{array}$ \\
\hline \multicolumn{4}{|l|}{ Probiotic drinks } \\
\hline $\begin{array}{l}\text { Milks, fruit } \\
\text { juices }\end{array}$ & $\begin{array}{l}\text { Lactobacillus casei; } \\
\text { Lactobacillus plantarum; } \\
\text { Lactobacillus reuteri }\end{array}$ & $\begin{array}{l}\text { Component probiotic strains } \\
\text { have proven beneficial } \\
\text { effects; accurate labelling, } \\
\text { helpful package inserts; } \\
\text { very palatable }\end{array}$ & Short shelf life \\
\hline \multicolumn{4}{|l|}{ Supplements } \\
\hline $\begin{array}{l}\text { Capsules, } \\
\text { tablets, } \\
\text { powders }\end{array}$ & $\begin{array}{l}\text { Various: mainly } \\
\text { Lactobacillus acidophilus, } \\
\text { often with bifidobacteria }\end{array}$ & $\begin{array}{l}\text { Some brands contain } \\
\text { probiotics with proven } \\
\text { beneficial effects; long } \\
\text { shelf life }\end{array}$ & $\begin{array}{l}\text { Quality assurance issues: many } \\
\text { brands contain contaminants, } \\
\text { lower than claimed numbers } \\
\text { and/or strains with no proven } \\
\text { beneficial effects; some tablets } \\
\text { or capsules may be difficult to } \\
\text { swallow }\end{array}$ \\
\hline
\end{tabular}

similar way, but fermentation is carried out with different probiotic strains, usually $L$ acidophilus.

Drinks containing probiotic bacteria include fermented milks and fortified fruit juices.

There are many brands of yoghurts and probiotic drinks available in supermarkets and other retail outlets.

A third source of probiotics is supplements consisting of freeze dried bacteria in capsule, tablet, or powder form. Such goods may be bought in health food shops and some pharmacies.

The constituents and relative merits of these types of probiotic products are summarised in table 1 .

When choosing a probiotic product, an important caveat is that many contain unknown or variable numbers of bacteria, and most have strains with no proven record of probiotic activity. There are many thousands of strains of lactobacilli, all of which differ; while many of them may indeed show beneficial activity, very few have actually been proven to do so.

\section{Prebiotics}

Some probiotic preparations also contain prebiotics such as FOS or GOS, but the amounts present are probably too small to have a significant effect. Although several synthetic prebiotic oligosaccharide compounds are available commercially, in the UK they have not yet been incorporated into generally available foods. The best sources of prebiotics at present thus remain vegetables such as artichokes, onions, and chicory.

\section{PROBIOTICS, PREBIOTICS, AND MALNUTRITION}

Malnutrition is remarkably common. It has been estimated that approximately $30 \%$ of the world's population suffer this condition in some degree, ${ }^{11}$ and it is by no means confined to developing countries. Two studies in the past 10 years showed that nearly $50 \%$ of patients admitted to hospitals in Europe and the USA were either malnourished or considered at risk. ${ }^{12}{ }^{13}$

This condition is well recognised among the elderly. According to a standard text, $7 \%$ of those living at home and apparently well come into this category, ${ }^{14}$ and the incidence doubles in subjects aged $>80$. Being housebound or ill are additional risk factors.
It is postulated that undernourishment leads to damage to the gut epithelium, causing decreased gut mediated immunity, reduced absorption of essential dietary components, and loss of appetite. A leaky gut allows intestinal flora to enter the circulation (a phenomenon known as translocation); this may predispose to septicaemia and infections at remote sites.

Probiotics are helpful in normalising the nutritional status of children, and the use of yoghurt has been suggested by the World Health Organisation for nutritional recovery. ${ }^{15}$ Probiotic species proved to show a positive effect include $L$ acidophilus, yoghurt organisms ( $L$ delbrueckii var bulgaricus and Streptococcus salivarius var thermophilus), L plantarum 299v, and Bifidobacterium lactis Bb12. ${ }^{11}{ }^{16-18}$ It would be interesting and instructive to determine whether such probiotic species can also help to correct malnutrition in the elderly.

Lactose intolerance is a common condition, and the associated symptoms seem to get worse with age. ${ }^{19}{ }^{20}$ These can be largely avoided by not consuming milk, but this strategy may severely limit intake of necessary dietary elements such as calcium. The condition is due to low levels of $\beta$-galactosidase (lactase) in the intestinal mucosal cells. It is commonly observed that fermented milk products such as yoghurts are better tolerated than unprocessed milk, ${ }^{3}$ and it is suggested that this is due at least in part to the $\beta$-galactosidase activities of the bacteria ( $L$ delbrueckii var bulgaricus and $S$ salivarius var thermophilus) used to ferment the yoghurt. This enzyme is released after these organisms have passed through the stomach, as they are lysed by the pancreatic secretions. On the other hand, bacteria associated with bioyoghurts ( $L$ acidophilus and B bifidum) are stable to bile, and are thus less able to relieve lactose intolerance, ${ }^{3}$ and the well recognised probiotic strain $L$ rhamnosus GG does not ferment lactose. ${ }^{4}$ Thus, ordinary live yoghurt is the preferred agent in elderly subjects with lactose intolerance.

Szilagyi draws attention to the similarity of symptoms in lactose maldigestion and in irritable bowel syndrome, and suggests that mis-diagnosis of either condition could arise. ${ }^{20}$ It is thus of interest that probiotics have been shown to be useful in irritable bowel syndrome. ${ }^{21}$

There is clear evidence from studies in animals and in man that prebiotics such as lactulose, inulin, FOS and GOS, given in large doses (10-40 g per day) can have beneficial effects of calcium bioavailability. ${ }^{22}$ An interesting result was obtained 
by van den Heuvel et al, who showed in a double blind randomised trial that GOS taken at $20 \mathrm{~g} /$ day increased calcium absorption by $16 \%$ in a group of postmenopausal women..$^{23}$ As the excretion of calcium in the urine was not increased, it can be supposed that the extra calcium was retained. These studies clearly raise hopes that long term consumption of an appropriate prebiotic may reverse or prevent osteoporosis; the definitive investigations remain to be carried out.

\section{PROBIOTICS, PREBIOTICS, AND CONSTIPATION}

Constipation is common in elderly people. ${ }^{24}$ The composition of the faecal flora changes with age, most markedly by a fall in numbers of bifidobacteria. ${ }^{25-27}$ While it is still not clear whether this a cause or the effect of constipation, it is known that changes in intestinal flora can alter intestinal motility, and the short chain fatty acids produced by probiotic bacteria (by bifidobacteria, in particular) have an important effect on transit time. ${ }^{28} 29$ A logical approach to relieving constipation is thus to increase the numbers of bifidobacteria, a strategy tried using prebiotics as well as probiotics.

As long ago as 1935, it was claimed that LAB could relieve constipation. ${ }^{7}$ Despite Ouwehand et al having recently stated "review of the literature does not substantiate this claim", there are at least five positive reports, specifically in elderly subjects:

- Japanese workers reported improvements in stool frequency in the elderly after taking yoghurt containing bifidobacteria. $^{30}$

- Ouwehand et al themselves found that a commercially available mixture of L rhamnosus LC705 and Propionibacter freundreichii JS brought about a $24 \%$ increase in defecation frequency in group of elderly subjects. ${ }^{31}$

- Matsumoto et al reported that yoghurt with added $B$ lactis LKM512 also significantly increased this measure. ${ }^{32}$

- Salminen and Salminen refer to an unpublished trial in which they found that $L$ rhamnosus GG increased the mean defecation frequency from 2.1 to 3.1 per week in elderly subjects in hospital. ${ }^{33}$

- Umesaki cites two trials in which oral administration of $L$ casei Shirota eased constipation and its related symptoms. $^{34}$

Prebiotics such as FOS, GOS, lactulose and inulin can act as dietary fibre, ${ }^{35}$ as well as being substrates for LAB and thus encouraging their growth in the intestine. The widely used laxative lactulose ${ }^{36}$ is also a prebiotic, as it is not attacked by human disaccharidases and is substrate for the bifidobacteria in the colonic flora, that catabolise it to smaller molecules, creating an osmotic effect. Some other prebiotics have also proven effective:

- Rajala et al, as the result of a randomised double blind study, recommended a fibre-containing yoghurt sweetened with lactitol as "a natural and effective means of treating chronic constipation" in elderly hospitalised patients. $^{37}$

- Teuri and Korpela found that GOS (9 g/day) relieved constipation in some but not all elderly subjects, mainly by making defecation easier. ${ }^{38}$

- Shitara reported that GOS was effective in Japanese subjects. $^{39}$

- Kleesen et al again found some subject-to-subject variation in their study comparing lactose and FOS (in the form of inulin), given to elderly subjects in dosages of $20 \mathrm{~g}$ increasing to $40 \mathrm{~g} /$ day; inulin had the more effective laxative action. ${ }^{40}$

Larger studies are needed to confirm the usefulness of prebiotics other than lactulose, as the individual effects reported in the above studies usually did not reach statistical significance.

\section{PROBIOTICS AND ANTIBIOTIC ASSOCIATED DIARRHOEA}

Diarrhoea is perceived as a common adverse event after taking an antibiotic. However, much of the evidence for this is anecdotal; the most reliable figures-from controlled clinical trials carried out for registration purposes-suggest an incidence of $<5 \%$ for most oral cephalosporins and coamoxiclav. ${ }^{41}$ This type of diarrhoea may be due to overgrowth in the intestine of toxigenic Clostridium difficile, and elderly subjects in hospital appear to be more susceptible than other patient groups. ${ }^{42}$

Probiotics, in particular the yeast Saccharomyces boulardii, have shown some promise in the prevention and treatment of antibiotic associated diarrhoea. ${ }^{43}$ Only one trial has been done specifically in elderly subjects, and this showed no benefit from taking $S$ boulardii. ${ }^{44}$ However, this study is seriously flawed, as the dose used (226 mg daily) was too low: other workers have shown positive effects at a dosage of $1 \mathrm{~g}$ per day. ${ }^{43}$ The authors of a recent meta-analysis of nine trials, ${ }^{43}$ eight of which were carried out in general populations that included some elderly patients (the ninth being the one referred to above), concluded that probiotics may be useful, but further trials were needed particularly in elderly patients (present author's emphasis).

\begin{tabular}{|c|c|c|}
\hline Indication & Usefulness of probiotics & Usefulness of prebiotics \\
\hline \multicolumn{3}{|l|}{ Nutrition } \\
\hline Malnourishment & $\begin{array}{l}\text { Possibly, by extrapolation } \\
\text { from results in children }\end{array}$ & \\
\hline Lactose intolerance & Yoghurt organisms helpful & \\
\hline Calcium availability & & GOS shown to be effective \\
\hline \multicolumn{3}{|l|}{ Bowel problems } \\
\hline Constipation & Helpful: at least five & Lactulose well established; \\
\hline $\begin{array}{l}\text { Antibiotic associated } \\
\text { diarrhoea }\end{array}$ & $\begin{array}{l}\text { succestul trials } \\
\text { Possibly, from results of trials } \\
\text { in general populations }\end{array}$ & \\
\hline Immune system & $\begin{array}{l}\text { Some immunological markers } \\
\text { improved; effects on clinical } \\
\text { status yet to be shown }\end{array}$ & $\begin{array}{l}\text { Some immunological markers } \\
\text { improved; effects on clinical } \\
\text { status yet to be shown }\end{array}$ \\
\hline
\end{tabular}




\section{PROBIOTICS, PREBIOTICS, AND THE IMMUNE SYSTEM}

The ability of the body to mount an effective defensive response to disease declines with age, a phenomenon known as immunosenescence. Elderly people may indeed be regarded as immunocompromised. ${ }^{45}$ Cellular immunity seems to be the most seriously affected, with decreased numbers of circulating CD3+ lymphocytes and diminished activity of natural killer (NK) cells. Clearly, any strategy that can boost immunity in the elderly is to be welcomed.

Various probiotic bacteria, including yoghurt organisms, $L$ johnsonii Lal, $L$ acidophilus, $L$ casei and $B$ lactis $\mathrm{Bb} 12$, have been shown on the basis of in vitro and ex vivo models to have immunostimulatory properties, including modulation of cytokine production, increased phagocytic activity of polymorphs, adjuvant effects on specific humoral responses, $\mathrm{T}$ lymphocytic function, and NK activity. ${ }^{46}{ }^{47}$

Several investigations show that probiotics stimulate the immune system in elderly subjects. Gill and colleagues report in a series of papers the beneficial effects of three week courses of L rhamnosus HNO01 or B lactis HNO19 in elderly healthy volunteers; they found significant increases in levels of $\alpha$-interferon, total lymphocyte counts, circulating counts of CD4+ and CD25+ cells, and NK tumoricidal activities. ${ }^{48-51}$ Of particular interest were the findings that improvements in immunological functions were more marked in subjects aged over 70 and in those with poor pretreatment parameters. Van de Water et al found that yoghurt consumption for one year decreased the incidence of allergies and serum IgE levels in a group of healthy elderly subjects. ${ }^{52}$

Guigoz et al investigated the effects of giving the prebiotic FOS, $8 \mathrm{~g}$ daily for three weeks, to frail elderly subjects in a nursing home. ${ }^{53}$ An increase in numbers of faecal bifidobacteria was accompanied by significant rises in counts of total lymphocytes, CD4+ and CD8+ cells. An unexpected finding was a fall in phagocytic activity of polymorphs and monocytes, as well as reduced expression of interleukin-6 mRNA in peripheral blood monocytes; the authors attributed these changes to a general decrease in inflammation. However, Bunout et al found that a prebiotic mixture of inulin and oligofructose did not augment the results of vaccination with influenzal and pneumococcal antigens. ${ }^{54}$

It remains to be demonstrated whether the apparently beneficial effects of probiotics and prebiotics on various immune parameters, as outlined above, is of practical significance. An interesting finding in this respect was made by Turchet et al who supplemented the diet of a group of healthy elderly subjects with $L$ casei for three weeks, and reported that the duration of "winter infections" (gastrointestinal or respiratory) was decreased by $20 \%$ compared with a control group. $^{55}$

\section{OTHER POSSIBLE USES OF PROBIOTICS IN THE ELDERLY}

Probiotics have been shown in clinical trials to be effective in a wide variety of conditions other than those discussed above. ${ }^{356}$ Although these studies have not specifically involved elderly subjects, it is not unreasonable to suppose that the results could also apply to this group.

An intriguing possibility is that LAB may have a role in prevention of malignancy. In vitro and animal studies suggest various possible anticarcinogenic effects, possibly by altering faecal enzymes so that production of potential carcinogens, such as nitrite and azo compounds, is minimised. ${ }^{57}$ The action of probiotics, described in the previous section, in increasing the activity of NK cells, whose targets include tumour cells, may also have a part to play in the prevention of development of cancers. There are grounds for optimism from epidemiological studies, some of which show lower incidences of some types of cancer associated with regular consumption of fermented milk products. ${ }^{58}$

Two randomised clinical trials from Japan indicated that $L$ casei Shirota significantly decreased the chance of recurrence of bladder tumours in man. ${ }^{59} 60$

\section{CONCLUSIONS}

Review of the literature suggests that three problems common in the elderly, namely, undernutrition, constipation, and the decline in efficiency of the immune system leading to a reduced capacity to resist infection, may all be beneficially affected by appropriate probiotic organisms (table 2). These are most conveniently taken either as yoghurts or as specific supplements. Much further work is necessary to determine long term outcomes and the most suitable probiotic strains. Prebiotics may also have a similar role.

\section{ACKNOWLEDGEMENTS}

I am very grateful to Dr Sheldon Stone for his critical appraisal of the manuscript.

\section{REFERENCES}

1 Kollath W. Ernährung und Zahnsystem. Deutsche Zahnärtz Z 1953:8(11):7-16.

2 Reid G, Sanders ME, Gaskins HR, et al. New scientific paradigms for probiotics and prebiotics. J Clin Gastroenterol 2003;36:105-18.

3 Marteau PR. Probiotics in clinical conditions. Clin Rev Allergy Immunol 2002;22:255-73.

4 Ouwehand AC, Salminen S, Isolauri E. Probiotics: an overview of beneficial effects. Antonie van Leeuwenhoek 2002;82:279-89.

5 Tamime AY. Fermented milks: a historical food with modern applications-a review. Eur J Clin Nutr 2002;56(suppl 4):S2-15.

6 Bibel DJ. Elie Metchnikoff's bacillus of long life. ASM News 1988;54:661-5.

7 Fuller R. History and development of probiotics. In: Fuller R, ed. Probioticsthe scientific basis. London: Chapman and Hall, 1992:1-8.

8 Stanton C, Gardiner G, Meehan H, et al. Market potential for probiotics. Am J Clin Nutr 2001;73(suppl):476S-83.

9 Gibson GR, Roberfoid MB. Dietary modulation of the human colonic microbiota: introducing the concept of prebiotics. J Nutr 1995;125:1401-12.

10 Rastall RA, Gibson GR. Prebiotic oligosaccharides: evaluation of biological activities and potential future developments. In: Tannock GW, ed. Probiotics and prebiotics: where are we going? Wymondham: Caister Academic Press, 2002:107-48.

11 Solis B, Samartin S, Gomez S, et al. Probiotics as a help in children suffering from malnutrition and diarrhoea. Eur J Clin Nutr 2002;56(suppl 3):S57-9.

12 McWhirter JP, Pennington CR. Incidence and recognition of malnutrition in hospital. BMJ 1994;308:945-8.

13 Gallagher-Allred CR, Voss AC, Finn SC, et al. Malnutrition and clinical outcomes: the case for medical nutrition therapy. J Am Diet Assoc 1996;96:361-6.

14 Thomas AJ. Nutrition. In: Tallis R, Fillit H, eds. Brocklehurst's textbook of geriatrics and gerontology. 6th Ed. Edinburgh: Churchill Livingstone, 2003:1057-71.

15 World Health Organisation. Nutrition for health and development. Geneva: WHO, 2000:9-10.

16 Saran S, Gopalan S, Krishna TP. Use of fermented foods to combat stunting and failure to thrive. Nutrition 2002;18:393-6.

17 Nopchinda S, Varavithya W, Phuapradit P, et al. Effect of bifidobacterium $\mathrm{Bb} 12$ with or without Streptococcus thermophilus supplemented formula on nutritional status. J Med Assoc Thai 2002;85(suppl 4):S1225-31.

18 Cunningham-Rundles S, Ahrne S, Bengmark S, et al. Probiotics and immune response. Am J Gastroenterol 2000;95(suppl 1):S22-5.

19 Salzman JR, Russell RM, Golner B, et al. A randomized trial of Lactobacillus acidophilus BG2FO4 to treat lactose intolerance. Am J Clin Nutr 1999;69:140-6.

20 Szilagyi A. Review article: lactose-a potential prebiotic. Aliment Pharmacol Ther 2002; 16:1591-602.

21 Hamilton-Miller JMT. Probiotics in the management of irritable bowel syndrome: a review of clinical trials. Microbial Ecology in Health and Disease $2001 ; 13: 212-6$.

22 Cashman K. Prebiotics and calcium bioavailability. In: Tannock GW, ed. Probiotics and prebiotics: where are we going? Wymondham: Caister Academic Press, 2002:149-74.

23 van den Heuvel EG, Schoterman MH, Muijs T. Transgalactooligosaccharides stimulate calcium absorption in post-menopausal women. J Nutr 2000; 130:2938-42.

24 Murray FE, Bliss CM. Geriatric constipation: a brief update on a common problem. Geriatrics 1991;46(3):64-8.

25 Mitsuoka T. Intestinal flora and aging. Nutr Rev 1992;50:438-46.

26 Hopkins MJ, Sharp R, Macfarlane GT. Age and disease related changes in intestinal bacterial populations assessed by cell culture, 16S rRNA abundance and community cellular fatty acid profiles. Gut 2001;48:198-205. 
27 Reuter G. The lactobacillus and bifidobacterium microflora of the human intestine: composition and succession. Current Issues in Intestinal Microbiology $2001 ; 2(2): 43-53$.

28 Scheppach W. Effects of short chain fatty acids on gut morphology and function. Gut 1994;35(suppl 1):S35-8.

29 Husebye $\mathrm{E}$. The stimulatory influence of the intestinal microflora on gastrointestinal motility and myoelectric activity of small intestine. In: Heidt PJ, Rusch V, van der Waaij D, eds. Gastro-intestinal motility. Old Herborn University Seminar Monographs \#9. Herborn: Herborn Litterae, 1997:41-52.

30 Tanaka R, Shimosaka K. Investigation of the stool frequency in elderly who are bed-ridden and its improvement by ingesting bifidus yoghurt. Japanese Journal of Geriatrics 1982; 19:577-82 (in Japanese).

31 Ouwehand AC, Lagstrom $\mathrm{H}$, Suomalainen $\mathrm{T}$, et al. Effect of probiotics on constipation, fecal azoreductase activity and fecal mucin content in the elderly. Ann Nutr Metab 2002;46:159-62.

32 Matsumoto M, Imai T, Hironaka T, et al. Effect of yoghurt with Bifidobacterium lactis LKM 512 in improving fecal microflora and defecation of healthy individuals. Journal of Intestinal Microbiology 2001;14:97-102 (in Japanese).

33 Salminen S, Salminen E. Lactulose, lactic acid bacteria, intestinal microecology and mucosal protection. Scand J Gastroenterol 1997;32(suppl 222):45-8.

34 Umesaki Y. Modification of gastro-intestinal function. In: Yakult Central Institute for Microbiological Research, ed. Lactobacillus casei strain Shirota. Tokyo: Yakult Honsha Ltd, 1999:118-28.

35 Roberfroid M. Dietary fiber, inulin and oligofructose: a review comparing their physiological effects. Crit Rev Food Sci Nutr 1993;33:103-48.

36 Kot TV, Pettit-Young NA. Lactulose in the management of constipation: a current review. Ann Pharmacother 1992;26:1277-82.

37 Rajala SA, Salminen SJ, Seppanen JH, et al. Treatment of chronic constipation with lactitol sweetened yoghurt supplemented with guar gum and wheat bran in elderly hospital patients. Comprehensive Gerontology A 1988;2:83-6.

38 Teuri U, Korpela R. Galacto-oligosaccharides relieve constipation in elderly people. Ann Nutr Metab 1998;42:319-27.

39 Shitara A. Effect of $4^{\prime}$-galactosyl-lactose on constipated old patients and intestinal bacteria. Med Biol 1988;117:371-3 (in Japanese).

40 Kleesen B, Sykura B, Zunft H-J, et al. Effects of inulin and lactose on fecal microflora, microbial activity and bowel habit in elderly constipated persons. Am J Clin Nutr 1997;65:1397-402.

41 Brumfitt W, Hamilton-Miller JMT. Cefaclor into the millennium. J Chemother 1999;11:163-78

42 Kelly CP, Pothoulakis C, Lamont JT. Clostridium difficile colitis. N Engl J Med 1994;330:257-62.

43 D'Souza AL, Rajkumar C, Cooke J, et al. Probiotics in prevention of antibiotic associated diarrhoea: meta-analysis. BMJ 2002;324:1361-4.
44 Lewis SJ, Potts LF, Barry RE. The lack of therapeutic effect of Saccharomyces boulardii in prevention of antibiotic-related diarrhoea in elderly patients. $J$ Infect 1998;36:171-4.

45 Aspinall R, Andrew D. Immunosenescence: potential causes and strategies for reversal. Biochem Soc Trans 2000;28:250-4.

46 Meydani SN, Ha W-K. Immunologic effects of yogurt. Am J Clin Nutr 2000;71:861-72

47 Blum S, Haller D, Pfeifer A, et al. Probiotics and immune response. Clin Rev Allergy Immunol 2002;22:287-309.

48 Arunachalam K, Gill HS, Chadra RK. Enhancement of natural immune function by dietary consumption of Bifidobacterium lactis (HNO19). Eur J Clin Nutr 2000;54:1-5.

49 Gill HS, Rutherfurd KJ, Cross ML, et al. Enhancement of immunity in the elderly by dietary supplementation with the probiotic Bifidobacterium lactis HNO19. Am J Clin Nutr 2001 ;4:833-9.

50 Sheih $\mathrm{Y}-\mathrm{H}$, Chiang B-L, Wang $\mathrm{L}-\mathrm{H}$, et al. Systemic immunity-enhancing effects in healthy subjects following dietary consumption of the lactic acid bacterium Lactobacillus rhamnosus HN001. J Am Coll Nutr 2001;20:149-56.

51 Gill HS, Rutherfurd KJ, Cross ML. Dietary probiotic supplementation enhances natural killer cell activity in the elderly: an investigation of age-related immunological changes. J Clin Immunol 2001;21:264-71.

52 Van der Water J, Keen CL, Gershwin ME. The influence of chronic yoghurt on immunity. J Nutr 1999;129:1492S-5.

53 Guigoz $Y$, Rochat F, Perruisseau-Carrier G, et al. Effects of oligosaccharide on the faecal flora and non-specific immune system in elderly people. Nutr Res 2002;22:13-25.

54 Bunout D, Hirsch S, Pia de la Maza M, et al. Effects of prebiotics on the immune response to vaccination in the elderly. Journal of Parenteral and Enteral Nutrition 2002;26:372-6.

55 Turchet $\mathbf{P}$, Laurenzano $M$, Auboiron $S$, et al. Effect of fermented milk containing the probiotic Lactobacillus casei DN-114001 on winter infections in free-living elderly subjects: a randomized, controlled pilot study. Journal of Nutrition, Health and Aging 2003;7:75-7.

56 Teitelbaum JE, Walker WA. Nutritional impact of pre- and probiotics as protective gastrointestinal organisms. Annu Rev Nutr 2002;22:107-38.

57 Rowland IR. Gut microflora and cancer. In: Leeds AR, Rowland IR, eds. Gut flora and health-past, present and future. International Congress and Symposium Series, No 219. London: Royal Society of Medicine Press, 1996:19-25.

58 Hirayama K, Rafter J. The role of probiotic bacteria in cancer prevention. Microbiol Infect 2000;2:681-6

59 Aso Y, Akaza H. Prophylactic effect of a Lactobacillus casei preparation on the recurrence of superficial bladder cancer. Urol Int 1992;49(3):125-9.

60 Aso Y, Akaza H, Kotake T, et al. Preventive effect of a Lactobacillus casei preparation on the recurrence of superficial bladder cancer in a double-blind trial. Eur Urol 1995;27:104-9. 